\title{
ERDEI RÓBERT
}

\section{AZ OPTIMÁLIS FEJLŐDÉST TÁMOGATÓ VÉDŐFAKTOROK}

\begin{abstract}
Absztrakt
A tanulmányban azokat a protektív faktorokat tekintem át, amelyek az optimális fejlödést hivatottak biztosítani, illetve a fennálló rizikóval szemben ellensúlyt képezhetnek a gyermek életében. A védőfaktorok általános meghatározásán túl bemutatom különböző csoportjaikat is. A legfontosabbak az egyénen belüli protektív faktorok, a családon belüli védőfaktorok, a nevelési-oktatási intézmények által nyújtott védőfaktorok és a tágabb társadalmi környezetben jelen lévő tényezők. A nevelési-oktatási intézmények védőfaktorait egy korábbi tanulmányban már ismertettem, ezért jelenleg a további fö csoportok bemutatására kerül a hangsúly.

A tanulmány a különböző protektív faktorok csoportosításán túl a hatásmechanizmusukat is bemutatja.
\end{abstract}

Kulcsszavak: reziliencia, védőfaktorok, protektív faktorok, fejlődési rizikó

\section{Bevezetés}

Egy korábbi tanulmányban bemutattam az oktatási-nevelési intézményekkel kapcsolatos legfontosabb rizikótényezőket és védőfaktorokat (Erdei, 2018). Jelen tanulmány keretein belül a védőfaktorok általánosabb megközelítésére helyeződik a hangsúly, így azok meghatározását, működési mechanizmusaik bemutatását, illetve a nevelési-oktatási intézményeken kívüli legfontosabb csoportjaik és az azokba tartozó tényezők ismertetését tűztem ki célul. Az optimális fejlődés ugyan minden gyermek számára kívánatos, de nem minden esetben nyílik erre lehetőség. A gyermeki fejlődésmenet sok esetben a rizikó különböző formái által jelentősen befolyásolt, így az ideális vagy optimális fejlődésmenet megtörhet. A fejlődési folyamatban azonban a protektív vagy védőfaktorok is kifejtik hatásukat, így a rizikónak kitett gyermekek fejlődése is visszatérhet az optimális kerékvágásba. Ezúttal a fejlődési rizikó tényezőinek csoportosítására nem térek ki, a fö hangsúlyt a védőfaktorok 
kapják. Azért is szükséges ez a megközelítés, mert pedagógiai szempontból nagy jelentösége van annak, hogy milyen iránymutatást kaphatnak a szakemberek a rizikó hatásának kitett gyermekek vonatkozásában. A lehetséges védőfaktorok sikeres azonosítása és működésbe hozása ugyanis hozzájárulhat a pedagógiai hatékonyság növekedéséhez.

\section{A védőfaktorok általános meghatározása és hatásmechanizmusai}

A protektív faktorok Biscoe (1999) meghatározása szerint hozzájárulnak az egyén jóllétéhez. Werner és Smith (1992) olyan módon definiálják a védőfaktorokat, mint amelyek a rizikófaktorok negatív hatását csökkentik az individuális fejlődésre vonatkoztatva. Olyan tényezőkként jelennek meg a protektív faktorok, melyek vagy az egyénre jellemző sérülékenységet (vulnerabilitást), vagy a környezetben megnyilvánuló és érvényesülő kockázatokat mérsékelni képesek. Az esetek jelentős részében ezek a tényezők szoros interakcióban állnak egymással, valamint a rizikótényezőkkel is, amelyek hatását különböző módon befolyásolják, például ellensúlyozzák vagy mérsékelik (Rahman, 1999). A rizikótényezők és védőfaktorok kapcsolatát illetően Ungar (2004) megállapítja, hogy ez leggyakrabban kaotikusként, viszonylagosként és komplexként írható le, figyelembe véve a kontextust is, amelyben megnyilvánulnak. Roberts és Steele (2009) kiemelik, hogy a védőfaktorok egyrészt csökkentik a rizikó hatását, másrészt lehetőséget biztosítanak az adaptív alkalmazkodásra. Egyidejủleg azt is hozzáteszik, hogy a védőfaktorok szerepüket csak a nehézségek kontextusában képesek kifejteni, amennyiben a nehézségek alacsony szintűek vagy meg sem jelennek az egyén életében, akkor a védőfaktorok nem müködnek. A védőfaktorokkal kapcsolatosan megjegyzendő, hogy elkülönülnek az erőforrásokat jelentő tényezőktől is. Utóbbiak mindenképpen pozitív hatással bírnak az egyénre a stressz jelenlététől vagy hiányától függetlenül. Fontos megjegyezni, hogy egy védőfaktor moderátorhatással bír a rizikó hatását illetően, míg az erőforrásfaktorok additív hatásúak.

A védőfaktorok képesek arra, hogy az egyének reziliens müködését támogassák, véli Chawla, Keena, Pevec és Stanley (2014). Ezen tényezők közé tartoznak a személyes minőségek, az egyén környezetének sajátosságai, valamint a környezeten belüli interakciók, amelyek a rizikó ellenére jó kimeneteket tesznek lehetővé. A reziliencia olyan interaktív folyamatra utal, amely során a gyerekek személyes erőiket mozgósítják, hogy a környezet erőforrásait képesek legyenek felkutatni és hasznosítani. Elias és Haynes (2008) szerint a védőfaktorok folyamatosan müködnek, amennyiben rendelkezésre állnak az egyén, a család és a közösség relációjában. Ez a feltételezés némileg ellentmond a Roberts és Steele (2009) által leírt működési mechanizmusnak, mivel ők azt vélelmezik, hogy a védőfaktorok kizárólag a rizikótényezőkkel együtt müködnek. 
A protektív faktorok képesek lehetnek arra, hogy az egyén rizikóhelyzetre adott válaszát módosítsák, befolyásolják, tehát moderátorokként működhetnek. Ha egy ilyen tényező képes csökkenteni a zavarok jelentkezésének valószínűségét nagy rizikójú csoportnál, de kis hatással bír alacsony rizikójú csoport esetében, akkor ezt a faktort jelentőségteljes tényezőként kell értékelnünk a gyermekek rizikóhelyzettel való megküzdésében (Jenkins és Keating, 1998). Megjegyzendő, hogy bizonyos tényezők bizonyos helyzetben rizikófaktorként jelennek meg, más kontextusban azonban sokkal inkább protektív szerepet töltenek be. Jellegzetes példa ezekre a faktorokra az agresszió, amelyet általában rizikótényezőként szokás értelmezni, akár a személy agresszív viselkedésére, akár az őt ért agresszióra vonatkoztatjuk, azonban proszociális, a közösség érdekeit szolgáló fajtája is ismeretes (Blum, 2002).

Masten és Powell (2003), a reziliencia jelentős kutatói, két alapvető megközelítési formát írnak le a védőfaktorok meghatározásánál, amelyek változófókuszú és személyfókuszú megközelítésekként határozhatók meg. A változófókuszú szemlélet a személyes kompetencia, valamint a nehézségek és a védőfaktorok közti összefüggésekkel és interakciókkal foglalkozik, amelyek alkalmasak a gyerekek közötti individuális különbségek leírására, illetve a gyermeket körülvevő világot jellemző kapcsolatokat és interakciókat is képesek megjeleníteni. Ezzel szemben a személyfókuszú stratégiák leginkább az iránt érdeklődnek, miként lehet beazonosítani a reziliencia kritériumainak megfelelő egyéneket. Az utóbbi megközelítés kevésbé helyez hangsúlyt a különböző folyamatok azonosítására, amelyek a védőfaktorok működésének és a rezilienciának specifikus területeire jellemzők, de egyidejűleg a reziliencia természetes megjelenésének aktuális megnyilvánulásait a változófókuszú nézőponttal ellentétben hatékonyabban képes megragadni.

A reziliencia jelenségét és megjelenését gyakran állítják párhuzamba a védőfaktorokkal. Wolin és Wolin (1993) nemcsak rezilienciáról, hanem rezilienciákról beszél, a védöfaktorok szinonimájaként használva ezt a kifejezést. A szerzőpár egy mandalát rajzolt, aminek a közepén az én mint a reziliencia fó ágense található, akit körülölelnek azok a védőfaktorok, amelyek a rizikókkal, ártalmakkal szemben képesek lehetnek az egyént megóvni. Ezeket a tényezőket Wolin és Wolin (1993) a következőkben határozta meg: függetlenség, kapcsolatok kialakításának és fenntartásának képessége, kezdeményezőkészség, humorérzék, kreativitás, moralitás, éles elme.

\section{A védőfaktorok csoportosítása}

A rizikófaktorokhoz hasonlóan a védőfaktorokat is több kategóriába sorolják a kutatók, amelyek gyakorlatilag megegyeznek a veszélyeztető tényezők csoportjaival (tehát egyénen 
belüli, családon belüli, iskolai és tágabb környezetre vagy társadalomra vonatkozó tényezők). Ezek közül jelen tanulmány keretein belül az egyén szintjén, a család vonatkozásában és a tágabb közösségben érvényesülő tényezőket tárgyaljuk, az oktatási-nevelési intézmények védőfaktorként működő jellemzőit lásd Erdei (2018) tanulmányában.

\subsection{Az egyénen belüli védőfaktorok}

Az egyénen belüli védőfaktorok bemutatása és felosztása jelen tanulmány keretein belül a rizikófaktorok kategorizálásához hasonlóan történik meg. A fejlődési rizikó tényezőit itt nem ismertetjük, de a rizikóval kapcsolatos legfontosabb vonatkozások összefoglalása Erdei (2015) ismertetésében megtalálható. Az egyénen belüli protektív faktorok közé, amelyekre diszpozicionális és/vagy temperamentumbeli jellemzőkként is utalnak, a szakirodalom számos különböző faktort sorol. Az egészségügyi-biológiai vonatkozású védőfaktorok között kiemelendők a fizikai és mentális egészség mutatói, de a könnyü temperamentum, illetve az úgynevezett ,jó természet” is a legjellemzőbb mutatók közé sorolható. A személyiségvonások közül említést érdemel az attribúciókhoz kötődő belső kontrollosság, a magas fokú szociabilitás, az énhatékonyság érzése és a fejlett humorérzék. Az egyéni szinten megnyilvánuló képességeket illetően a magasabb szintű intellektuális szerveződés és az általános értelemben jobb kognitív képességek, a hatékonyabb kommunikációs készség, a szociális vonzerő, az alkalmazkodásra való képesség és a reális helyzetértékelés bizonyult a legjelentősebb védőfaktornak. Az egyénre jellemző viselkedéses jegyek közül kiemelkednek a hit, a kompetencia, a kontroll, a szociális orientáció, a pozitív modellek felé orientálódás faktorai. Hangsúlyozandó, hogy a reziliencia eléréséhez a kevesebb negatív életesemény és a körülmények szerencsés alakulása is hozzájárul, ezek azonban a személy befolyásán kívül álló tényezők, még ha nagy mértékben érintik is az adott egyént.

\subsubsection{Egészségügyi-biológiai faktorok}

- Jó általános egészségi állapot (Werner, 2000), normál születési súly és megfelelő testsúly a későbbi életkorban (Punamäki, Qouta, Miller és El-Sarraj, 2011);

- Az idegrendszer nagymértékü plaszticitása (Noltemeyer és Bush, 2013);

- Könnyű temperamentum, illetve a más személyekből pozitív válaszokat kiváltó temperamentumbeli jellemzők, mint például a magas aktivitási szint, alacsony mértékủ ingerlékenység, alacsony szintű stressz, magas fokú szociabilitás, az új élmények élvezetének képessége, nyugodtság, ,jó” természet (Verlinden, Hersen és Thomas, 2000; Cox, 2004, Werner és Smith, 1992, Lachman, Poblete, Ebigbo, Nyandiya-Bundy, Bundy, Killian és Doek, 2002). 


\subsubsection{Személyiségvonások}

- Az egyénre jellemző magas szintű önbecsülés (Burt, 2002), asszertivitás, önérvényesítő képesség (Blum, 2002; Noltemeyer és Bush, 2013), az autonómia érzése (Werner, 2000), függetlenség (Blum, 2002), magas szintű koherenciaérzés, ami segítséget nyújt a hatékony megküzdési mód kiválasztásában (Torsheim, Aaroe és Wold, 2001);

- Az én hatékonyságának érzése (Masten, 2001), ezzel összefüggésben pedig magas szintü önkontroll (Masten, 2001; Wills és O'Carroll Bantum, 2012), életerő (Werner és Smith, 1992), a remény érzése (Masten, 1999; Venters Horton és Wallander, 2001);

- Belső kontrollosság, ami legnagyobb mértékben az anyától, illetve a családtól származó elvárásokon alapul (Himelein és McElrath, 1996; Burt, 2002), a felelősség külső oknak tulajdonítása (Heller, Larrieu, D'Imperio és Boris, 1999) - fontos megjegyezni, hogy ez utóbbi kutatási eredmény a belső kontrollossággal mint védőfaktorral kapcsolatos megfigyeléseknek bizonyos mértékig ellentmond;

- Mindkét nem esetében védőfaktort jelent több tipikusan nőiesnek tartott értékeknek tulajdonított jelentőség (finom, gondoskodó, szociálisan érzékeny, jó kifejezőkészségű, kíváncsi) (Blum, 2002), a pozitív érzelmek átélésének képessége, mivel ez hozzájárul az élettel való elégedettséghez és a jobb élethez szükséges erőforrások megtalálásához és felhasználásához (Cohn, Fredrickson, Brown, Mikels és Conway, 2009);

- Erős munkaerkölcs és kitartás (Noltemeyer és Bush, 2013);

- Alkalmazkodókészség, szociábilis személyiség (Masten, 2001; Masten és Powell, 2003), tisztelet önmaga és mások iránt (Masten és Powell, 2003);

- Fejlett humorérzék (Smokowski, Reynolds és Bezrucko, 1999).

\subsubsection{Képességek}

- Átlag feletti kognitív képességek, illetve normális mintázatot mutató kognitív fejlődés (Verlinden és mtsai., 2000; Masten, 2001), valamint legalább átlagos szintü intelligencia (Werner és Smith, 1992), magas fokú teljesítményorientáció (Blum, 2002);

- Jó kommunikációs készség (Blum, 2002);

- Szociális vonzerő (Masten, 2001) és fizikai vonzerő (Blum, 2002), a szeretetreméltóság érzése (Blum, 2002);

- Az empátiára való képesség (Masten, 2001), olyan megküzdési stratégiák alkalmazása, amelyek a helyzet megoldására fókuszálnak (Henley, 2010), a változásokhoz való alkalmazkodás képessége (Henley, 2010); 
- A környezet reális értékelése (Guo és Tsui, 2010);

- Az egyén képessége arra, hogy önmagát megnyugtassa (Elias és Haynes, 2008).

\subsubsection{Viselkedéses jegyek}

- Vallásosság, hit (Smokowski és mtsai., 1999), spiritualitás (Blum, 2002; Smith, Webber és DeFrain, 2013), hit az élet értelmességében és abban, hogy az egyén képes kontrollt gyakorolni a sorsa fölött (Laursen és Birmingham, 2003), pozitív illúziók, az események fölötti kontrollba vetett hit és a jövőt illető túlzott optimizmus (Himelein és McElrath, 1996);

- Megfigyelhető, hogy a lányok/nők inkább keresnek társas támogatást kortársaiknál, mint a fiúk/férfiak (Smokowski és mtsai., 1999; Blum, 2002), valamint a nők inkább orientálódnak a törődés és a másokkal való kapcsolat felé (Smokowski és mtsai., 1999; Blum, 2002);

- A fiúk ezzel szemben úgy alakítják az életüket, hogy kevésbé váljanak túlzottan involválttá másokkal kapcsolatban, ami az ő esetükben éppúgy képes védőfaktorként működni, mint a lányok esetében a nagyobb mértékü bevonódás interperszonális kapcsolatokba (Smokowski és mtsai., 1999; Blum, 2002), a fiúk jobban kontrollálják érzelmeiket, érzelmileg kevésbé sérülékenyek, kedvezőbb a testképük, boldogabbak (Smokowski és mtsai., 1999; Blum, 2002);

- A politika és a szociális kérdések iránti érdeklődés (Blum, 2002), a kíváncsiság és a környezet felfedezésének vágya (Henley, 2010);

- Segítség kérésének képessége szükség esetén (Werner, 2000), a szociális támogatás adekvát felhasználásának képessége (Smokowski és mtsai., 1999);

- Pozitív szociális orientáció (Verlinden és mtsai., 2000);

- Pozitív felnőtt szerepmodellek megtalálása és a velük való kapcsolat kialakításának képessége (Werner, 2000);

- A felelősségvállalás képessége (Blum, 2002), amit szükség esetén másokkal is szembeszállva képes az egyén megvalósítani (Christie, Harley, Nelson és Jones, 2008), gondolkodás a cselekvés előtt (Henley, 2010);

- Kitartás feladathelyzetekben nehézségek esetén is (Blum, 2002), céltudatosság, jó célok állításának képessége (Werner, 2000);

- A személyes kompetencia különböző területeinek megléte, mint hobbik, többféle érdeklődési terület, sporttevékenység (Werner, 2000; Masten és Powell, 2003; Afifi és MacMillan, 2011);

- A múlt kontrollja, az egyén képes beszélni fájdalmas élményeiről, vagy eljátszani őket, nem rágódik rajtuk (Lachman és mtsai, 2002). 


\subsubsection{Az egyént érintő, de rajta kívül álló faktorok}

- Jó szerencse (Masten, 1999);

- Kevesebb negatív életesemény (Blum, 2002);

- Olyan korai tapasztalatok, amelyek leleményessé tették a gyermeket (Lachman és mtsai., 2002).

\subsection{A családon belüli védőfaktorok}

A családi környezetben megnyilvánuló védőfaktorok sok esetben a családi rizikó ellentéteit jelentik, azonban a teljes kép árnyaltabb ennél. A familiáris kontextus protektív faktorainak kategorizálására a családi kapcsolatokat, a család működésének mechanizmusait, illetve a családot támogató tényezőket használtam fel felsőbb kategóriákként. A családi kapcsolatok között a pozitív melegség, a hozzáférhetőség, a konfliktusmentesség segíti leginkább a fejlődés optimális menetének megőrzését. A működésben az elvárások, a gyermek bevonódása, illetve az erőforrások minél jobb felhasználása bizonyultak a legjelentősebbnek. A családot támogató tényezők közül kiemelendő a tágabb család által nyújtott segítség, illetve a családon kívüli, kompetens segítők közreműködése.

\subsubsection{A családon belüli kapcsolatok}

- Gondoskodó, erős kapcsolat családtaggal vagy más kompetens, proszociális felnőttel, akiben a gyermek feltétel nélkül megbízhat (Verlinden és mtsai., 2000, Masten és Powell, 2003); legalább egy olyan személy a gyermek életében, aki támogatást biztosít egészséges fejlődéséhez és tanulásához, bizalmat, szeretetet, elkötelezettséget, megértést, tiszteletet, érdeklődést mutat irányába (Laursen és Birmingham, 2003; Lachman és mtsai., 2002); pozitív anya-gyerek kapcsolat (Blum, 2002; Malmberg és Flouri, 2011);

- A gyermek számára hozzáférhető felnőtt (Laursen és Birmingham, 2003), kis családméret (Rahman, 1999), együttélés mindkét szülővel (Masten, 1999), a biológiai apa részese a gyermek életének, legalább valamilyen szinten (Fagan és Palkovitz, 2007);

- Családi konfliktusok alacsony szintje (Rahman, 1999);

- A szülők válása utáni újraházasodás védőfaktort is jelenthet (Huffmann, Mehlinger és Kerivan, 2000);

- Kooperatív szülői stílus (Rahman, 1999), pozitív szerepmodellek (Grotberg, 2003);

- Jó hatással bír a gyermekre, ha a depresszióval küzdő szülő alacsonyabb szintű pszichológiai kontrollt gyakorol fölötte (Malvar Pargas, Brennan, Hammen és Le Brocque, 2010). 


\subsubsection{A család mủködése}

- Meleg, strukturált és pozitív fegyelmezési eljárásokat alkalmazó nevelési stílus (Masten és Powell, 2003, Bass és Darvas, 2008), a gyereket meghallgatják és beszélgetnek vele (Christie és mtsai., 2008); a szülő figyelemmel kíséri és felügyeli gyermeke tevékenységét (Lachman és mtsai., 2002; Christie és mtsai., 2008); világos és követhető szabályok állítása (Werner, 2000); magas szintű elvárások támasztása a gyermekkel szemben (Laursen és Birmingham, 2003; Banatao, 2011); határozott szülöi stílus (Lachman és mtsai., 2002); a családtagok egymás iránti elköteleződése magas (Brown, Howcroft és Muthen, 2010); magasabb szintű családi működés (Kim és Yoo, 2010);

- A szülők mentális egészsége (Punamäki és mtsai., 2011); a szülők érzelmi stabilitása (Reed-Victor, 2003);

- A gyerek lehetőséget kap a család céljaihoz való hozzájárulásra (Christie és mtsai., 2008); a gyerek viselkedését és egyéniségét elfogadják és megfelelően reagálnak rá (Werner, 2000); jó minőségủ a család közösen töltött ideje (Christie és mtsai,. 2008; Brown, Howcroft és Muthen, 2010); a család stabilitása és kohéziója a gyermeki kompetencia és szociális bevonódás irányába hat (Cox, 2004); erős a családi kohézió mértéke (Burt, 2002) és a család koherenciája (Retzlaff, 2007); a szülők

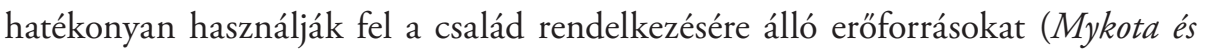
Muhajarine, 2005);

- Stabil környezetben él a család (Blum, 2002; Afffi és MacMillan, 2011); az otthon életének megfelelő irányítása (Werner, 2000); világos struktúrájú, felépített életritmus egy tiszta, rendezett és nem túlzsúfolt otthonban (Lachman és mtsai., 2002);

- Játékokat és egyéb anyagokat biztosítanak a gyermeknek (Christie és mtsai., 2008); a környezet felderítésének és az egyedül töltött időnek biztonságos lehetőségei is adottak számára (Christie és mtsai., 2008); hatékony problémamegoldási módozatok tanítása (Lachman és mtsai., 2002); a szülők érdeklődnek a gyermek érdeklődési területei iránt (Blum, 2002);

- A gondozók viselkedése, amely a gyermek egészségét támogatja, pl. rendszeres étkezés, mindennapos fogmosás (Yoo, Slack és Holl, 2010); jó minőségű gondozás az első életév folyamán (Christie és mtsai., 2008);

- A család pozitív jellemzői erősebben hatnak a lányokra (Cox, 2004).

\subsubsection{A családot támogató tényezők}

- A tágabb család támogató hatása (Werner, 2000; Greeff, Vansteenwegen és Herbiest, 2011; Bass és Darvas, 2008); a szülőt helyettesítő felnőttekkel kiala- 
kult érzelmi kötődések, pl. nagyszülők, idősebb testvérek vonatkozásában, melyek a bizalmat, autonómiát és kezdeményezőkészséget erősítik (Werner és Smith, 1992);

- Az anya magasabb iskolai végzettsége (Blum, 2002; Bass és Darvas, 2008);

- Kompetens tanácsadók, külső szakemberek közreműködése (Retzlaff, 2007).

\subsection{A tágabb közösség, illetve a társadalom szintjén érvényesülő protektív tényezők}

A közösségi és társadalmi szinten megjelenő erőforrások csoportosítása során a közösségi erőforrásokba besorolásra kerültek az olyan támogatások, amelyek az egyén jóllétét és sikeres alkalmazkodását segítik. A társadalmi szintű védőfaktorok nyilvánvalóan a szűkebb közösségek életén túlmutató, össztársadalmi szinten érvényesülő tényezőket jelentik. A közösségek szintjén a bántalmazás és elhanyagolás megszüntetése, az egyházi és más pozitív orientációjú közösségek és azok vezetőinek vagy tagjainak közvetlen hatása, valamint a jó szomszédság a legfontosabb védőfaktorok. Társadalmi szinten a sokféleség értékként kezelése, az értékorientált szerveződés, illetve a széles körủ támogatások és lehetőségek biztosítása óvja meg leginkább a fejlődést.

\subsubsection{Közösségi erőforrások}

- Egyházi (Werner és Smith, 1992) és más közösségek támogatása (Greeff, Vansteenwegen és Herbiest, 2011);

- Szülőhelyettesek, pl. szomszédok, kortársak, egyházi vagy ifúsági vezetők, a közösség idősebb tagjai, akik támogatóak, és tanácsot adnak szükség esetén (Laursen és Birmingham, 2003); proszociális viselkedésű személyekkel fenntartott kapcsolatok (Verlinden és mtsai., 2000);

- A bántalmazó közegből eltávolítják az egyént (Rahman, 1999); jó minőségű és stabil nevelöotthonba helyezés (Rahman, 1999);

- A közösség lehetőséget teremt az egyén önkontrollfunkcióinak fejlesztésére (Alvord és Johnson Grados, 2005);

- A lakókörnyezet/szomszédság minősége, a rendelkezésre álló közösségi erőforrások (Christie és mtsai., 2008); magasabb szintű közösségi szerveződés (Noltemeyer és Bush, 2013).

\subsubsection{Társadalmi szintü védőfaktorok}

- A pihenés és a kikapcsolódás lehetőségeinek biztosítása (Christie és mtsai., 2008);

- A társadalom értékorientált szerveződése (Reed-Victor, 2003);

- Biztonságos és nem zsúfolt lakókörnyezet biztosítása (Reed-Victor, 2003);

- Magasabb szocioökonómiai státusz (Huffmann és mtsai., 2000); 
- Elköteleződés proszociális értékeket mutató intézmények felé (Verlinden és mtsai., 2000);

- Nagyra értékelt kulturális pluralizmus (Mykota és Muhajarine, 2005).

\section{A protektív fajtorok további csoportosítása és hatásmechanizmusai}

Fontos megjegyezni, hogy a három nagyobb kategória mellett még a nevelési-oktatási intézmények részéről megnyilvánuló védőfaktorokkal is számolni kell (lásd ezek összefoglalását Erdei, 2018). Ezekre jelen tanulmány keretei között nem térek ki, mindössze egyetlen olyat tartok szükségesnek megemlíteni, amely mind az intézményes nevelés keretein belül, mind a család, mind pedig a tágabb közösségek vagy akár a teljes társadalom vonatkozásában értelmezhető, ez pedig a valahová tartozás érzése (sense of belonging). Bath (2009) kiemelt jelentőségűnek tartja a valahová tartozás érzését, amelyre Christie és munkatársai (2008) is jelentős hatású védőfaktorként utalnak. Az odatartozás érzése az iskolai közegben Bath (2009) szerint elengedhetetlenül összekapcsolódik a gyermekek aktív részvételével az osztályban. Hart, Blincow és Thomas (2007) a reziliencia jelenségének terápiás felhasználása során is kiemelt jelentőségűnek tekinti a „valahová tartozás” érzését. Ez az érzés lehetővé teszi a gyermeknek, hogy pozitív, értékes kapcsolatokat alakítson ki a családon, baráti társaságon, illetve oktatási-nevelési intézményeken belül. Egy jó óvodai vagy iskolai közeg képes ezt nyújtani a tanulóknak, akik annál könnyebben képesek identifikálódni egy közösséggel, intézménnyel, minél inkább képes az biztonságot jelentő és befogadó-elfogadó tényezőként megjelenni. Számukra is fontos lesz az, hogy ez az én iskolám, óvodám, osztályom. Avalahová tartozás érzése természetesen több módon is megjelenhet a gyermek életében.

A védőfaktorok eddigiekben ismertetett felsorolása és kategorizálása természetesen nem az egyetlen lehetséges mód az értelmezésükre. Grotberg (1997a, 1997b, 2003) a védőfaktorokat az egyén köré szerveződőnek tekinti, és így sorolja őket három nagyobb kategóriába. Maguk a védelmet jelentő tényezők gyakorlatilag megegyeznek a korábban felsoroltakkal, de osztályozásuk más szempontja miatt érdemes ezt a megközelítést is megemlíteni.

Az első csoportot a „nekem van” faktoraiként írja le, amely a külső támogatásokat és erőforrásokat foglalja magába. Ide sorolhatók a biztos kapcsolatok, az otthon struktúrája, a szerepmodellek, az autonómia támogatása, hozzáférés a különféle szolgáltatásokhoz (oktatás, egészségügy, jóllét, biztonság), tehát mindazok az erőforrások, amelyekkel a személy rendelkezik, vagy amelyekhez hozzáfér. 
A második csoportba az „én vagyok” faktorai tartoznak. A belső erőket jelenti, mint a szeretetreméltóság, megfelelő temperamentum, remény, hit, bizalom, felelősségtudat, tehát a védőfaktorok e csoportja a személy saját tulajdonságait és diszpozícióit foglalja magába.

A harmadik csoportot az „amit tudok” tényezői alkotják. Szociális és interperszonális képességek sorolhatók ide, mint a problémamegoldás, impulzuskontroll, saját és mások temperamentumának helyes felmérése, stabil kapcsolatok keresése. Ez a kategória a személy és környezete közötti interakciók fontosságára utal.

Elias és Haynes (2008) a legjelentősebb védőfaktorokat a szociális-érzelmi kompetenciában és az egyén által észlelt társas támogatásban azonosítja. A védőfaktorok leírhatók primer és szekunder faktorokként is. A primer faktorok már a születéstől jelen vannak, mint a pozitív temperamentum, a kognitív kompetencia, a nem (ezekben a vonatkozásokban a lányok előnyben vannak a tapasztalatok alapján), illetve az elsőszülöttség. Ezzel szemben a szekunder faktorok azok, amelyek a környezettel folytatott interakció során, sikeresen megoldott fejlődési feladatok eredményeként alakulnak ki a gyermekben, mint a pozitív társas viselkedés, az egészséges önértékelés és énhatékonyság-érzés, az autonómia, a szociális készségek, a humor (Wustmann, 2004; Lösel és Bender, 1999; Niebank és Petermann, 2002; Werner, 2000).

A reziliencia és ezzel együtt a védőfaktorok egyik legjelentősebb kutatóját, Emmy Wernert (2000) az érdekelte, hogy mi az, ami jóra fordította a Kauai-vizsgálat rizikós egyharmadának életét olyannyira, hogy sokan közülük még a nem rizikós csoport tagjainál is jobban teljesítettek. A longitudinális vizsgálat eredményeit elemezve ő a következő védőfaktorokat találta kulcsfontosságúnak:

- A szülő életkora, fiatalabb anya jobb a fiúknak, idősebb apa jobb a lányoknak;

- Négy vagy kevesebb testvér;

- Több mint két év különbség a reziliens gyerek és a következő testvér között (akik így nem számítanak versengő testvérnek);

- Alternatív gondozók, pl. apa, nagyszülők, testvérek jelenléte a gyermek életében;

- Az anya dolgozik (nem otthon);

- Csecsemőkorban az elsődleges gondozó által nyújtott figyelem mennyisége;

- A háztartás szabályai és struktúrája;

- Támogató kapcsolatok a tágabb családban és a barátok között;

- A reziliens fiúk gyakran elsőszülöttek (Werner, 2000; Cox, 2004).

Ez a csoport harminc-, illetve negyvenévesen (két kivételtől eltekintve) továbbra is sikeresnek bizonyult az életvezetésében. A reziliens gyerekek leginkább abban különböztek nem reziliens társaiktól, hogy szoros családi kötelékek és külső támogatási lehetőségek 
álltak rendelkezésükre. Werner kutatásai arra is rámutattak, hogy a nemnek is szerepe van a reziliencia alakulásában. A kompetens iskolai teljesítmény tízéves korban fiúknál, míg a tizennyolc éves kori személyes hatékonyság, magas önértékelés és az élet irányítása feletti kontroll érzése a lányoknál jelzett előre sikeresebb felnőttkori alkalmazkodást. A fiúk jobban kitettek a rizikófaktorok hatásainak az élet első tíz évében. Werner adatainak többváltozós elemzése azt mutatta, hogy a temperamentum, a társaságkedvelő személyiség, legfőképpen pedig a korai kötődés jelentős szerepet játszottak a reziliens gyerekek életében (Cox, 2004), így ezeknek a védőfaktoroknak különös hangsúlyt kell kapniuk, amennyiben erre lehetőség van. Solt (2012) azt találta, hogy a sérülékeny, rizikónak kitett fiatalok életében azonosíthatóak olyan fordulópontok, amelyek döntő hatással bírtak életük pozitív vagy negatív irányba fordulására. A külső protektív tényezők addig tudnak pozitív irányban hatni, amíg a gyermekben, fiatalban nem rögzült az elutasítás. A szabálykövető fiatalok esetében azok a fordulópontok, amelyek tőlük is függtek (pl. baráti társaság választása vagy egy kapcsolat kezdete), az esetek kilenctized részében pozitív hatásúak voltak. Ez az adat arra utal, hogy az egyéni választás, döntés nagyban meghatározza az életpálya alakulását.

Ahogy arra már korábban utaltam, az élet során a rizikó- és protektív faktorok folyamatos interakcióban vannak. Jessor, Van Den Bos, Vanderryn, Costa és Turbin (1995) a védőfaktorokat belső és külső klaszterekre osztotta, az előbbibe a személy önészleléssel és szociális devianciával kapcsolatos attitűdjei, míg az utóbbiba pl. a család, az otthon vagy a kortárs csoport jellemzői tartoznak. Masten és Garmezy (1985) a protektív faktorokat három kategóriába sorolta: az individuális jellemzők, a családon belüli, illetve az azon kívüli támogató kapcsolatok csoportjába. A reziliencia kutatásával kapcsolatos eredmények pedagógiai alkalmazhatósága leginkább azon a vélekedésen alapul, hogy a reziliens viselkedést valószínűvé tevő faktorok megváltoztathatóak (Benard, 1993; Masten, Best és Garmezy, 1990). Ezek közé tartoznak a Benard, illetve a Wolin és Wolin által ismertetett rezilienciajellemzők is, valamint ide sorolható az idő megfelelő kihasználása, az oktatáspolitikai és az iskolai gyakorlatra vonatkozó kérdések is (McMillan és Reed, 1994). Ezek közül jellemzően a megfelelően strukturált osztálytermet emelték ki mint lehetséges védőfaktort (Pierce, 1994), ezen túlmenően pedig a pedagógus szerepét, amellyel a tanulók saját teljesítményükbe vetett hitét alakítja a meglevő külső rizikók ellenére (Pajares és Valiante, 1997). A tanár személye és viselkedése, cselekedetei önmagukban is védőfaktorként funkcionálhatnak, amint erre többen (Benard, 1991, Wolin és Wolin, 1993, Pajares és Valiante, 1997) rámutatnak. Ezzel együtt a legjelentősebb védőfaktort a tanuló szoros, bizalomra épülő, egészséges kapcsolata jelenti a felnőtt személlyel otthon, az iskolán vagy valamely közösségen belül (Werner, 2000).

Maier (2005) hangsúlyozza, hogy a rizikó- és védőfaktorok működése nem lineáris. Szinte lehetetlen olyat találni, amelynek működése minden helyzetben egyértelmüen 
pozitív vagy negatív hatást gyakorol. A rizikót növelő és csökkentő tényezők rendkívül bonyolult módon működnek. A faktorok kumulálódnak, azonban ez sem egyértelműen és lineárisan történik. Ha egy rizikó jelenik meg, az nem növeli meg a rossz kimenet valószínűségét, ha azonban több van jelen, az kritikus hatású lehet. Hasonló hatás mutatkozik a rizikót csökkentő faktoroknál. Minél több rizikó és ártalom áll fenn, annál több védőfaktor szükséges ezek negatív hatásait kiegyenlíteni és mérsékelni (Lösel és Bender, 1999; Rolf, 1999; Kaplan, 1999).

A disztális rizikófaktorok gyakran csak úgy tudják kifejteni a hatásukat, ha proximális faktor is jelen van, ilyen lehet például a szegénység, amely önmagában nem jelent különösebb rizikót a fejlődésre, ha a családban harmonikus klíma és kedvező nevelés áll fenn. Tény az is, hogy a rizikótényezők ritkán jelentkeznek önmagukban. A krónikus szegénység gyakran jár együtt munkanélküliséggel, alkoholfüggőséggel, a szülő pszichés megbetegedésével, rossz táplálkozással, kedvezőtlen lakáskörülményekkel (Wustmann, 2004), amelyek proximális faktorokként hatva a gyermekre már a szegénységet mint disztális rizikótényezőt is beemelik a müködő rizikófaktorok közé. Danis és Szilvási (2011) szerint az empirikus kutatások összességében azt mutatják, hogy nem a szülői minőség a legfontosabb magyarázó tényező a szegénység és a gyerekek jóléte közötti összefüggés magyarázatára. A szegénység nem önmagában befolyásolja a gyerekek intellektuális fejlődését, hanem közvetítő változókon át hat, mint az otthoni környezet fizikai jellemzői, a kognitív stimuláció minősége, a gyermek egészségi állapota, a szülői stílus és bánásmód, és a napközbeni gondozás minősége.

Egy jellemző pozitív vagy negatív hatása nem független a mértéktől sem. Pl. az önértékelés pozitív volta kedvező hatással bír a nehézségekkel való szembenézés során, de a bűnelkövető fiataloknál is megfigyelhető az önértékelés magas szintje. Ebben az esetben a magas szintü önértékelés kifejezett rizikótényezőt jelent (Maier, 2005), fontos lenne tehát az önértékelés reális szintjét kialakítani a gyermekeknél.

A gyermekek életkora és neme is befolyásolja a rizikó- és védőfaktorok hatásait. Werner (2000) szerint fontos azt látni, hogy milyen típusú rizikónak mely életkorban van kitéve a gyermek. Más védőfaktorok jelentősek más életkorokban, így kora gyermekkorban a pozitív temperamentum és az egészség jelent védőfaktort, míg középső gyermekkorban a kommunikációs és problémamegoldó készségek, illetve a felelős, kompetens felnőtt jelenléte a gyerek életében bizonyulnak a legfontosabb védőhatásoknak. Ifjúkorban a belső kontrollosság és a pozitív énkép jelentik a legkiemelkedőbb protektív faktorokat (Werner, 2000). A gyermekkorban védőfaktorszerepet betöltő folyamatos anyai gondoskodás az ifjúkorban már kifejezett rizikót jelenthet.

A nem szerepe sem elhanyagolható a rizikó hatásában. A fiúk az élet első évtizedében veszélyeztetettebbek a lányoknál, különösen a biológiai rizikókra, a családi diszharmóniára 
és az alacsony szocioökonómiai státuszra. A lányok a serdülőkor végén mutatnak több pszichés problémát (Werner, 2000). A rizikót csökkentő tényezők közül is bizonyosak a lányoknál, mások a fiúknál hatnak inkább. Kora gyermekkorban a fiúknál a család stabilitása és az anyához füződő pozitív kapcsolat, lányoknál a könnyen kezelhető temperamentum a fó védőfaktor. A gyermekkor közepén a fiúknál az autonómiára törekvés, a lányoknál a pozitív szociális kapcsolatok a kortársakkal, ifuúkorban a fuúknál a mások által nyújtott szociális támogatás (szülő, tanár), lányoknál a személyes tulajdonságok (önértékelés, problémamegoldó képesség, belső kontrollosság) jelentik a fö védőfaktort (Werner és Smith, 1992; Werner, 2000).

A nevelési környezet bizonyos specifikumai is nemhez kötötten működhetnek védőfaktorként. A fiúknál különösen jelentős a világos struktúrákkal és szabályokkal operáló nevelés, amelyben az érzéseket nem nyomják el. Egy férfi családtag fontos azonosulási modellt jelent. Lányoknál az önállóság hangoztatása és egy nőnemű családtag megbízható támogatása kiemelten fontos (Blum, 2002; Masten és Powell, 2003).

A rizikó- és védőfaktorok kétarcúak. Bizonyos körülmények között éppen ellentétes hatást válthatnak ki. Pl. a kortárs kapcsolatok segíthetnek az ártalmak leküzdésében, illetve fejlesztő hatással bírhatnak a gyerekre, de ha a kortárs kapcsolatokat utcagyerekek jelentik, akkor megnőhet a bünelkövetés valószínűsége, így már nem beszélhetünk védőfaktorról (Wustmann, 2004).

Grotberg (2003) kiemeli, hogy nem minden gyerek fogja az összes ilyen faktort felhasználni, mint ahogy a rizikófaktorok közül sem mind érinti a gyerekeket. Nyilvánvalóan nagyon kevés az esélye annak, hogy egy gyermeket a rizikófaktorok többsége érintsen, de ahogyan a Jenkins és Keating (1998) által összeállított rizikóindex mutatója igazolta, négy rizikótényező egyidejü jelenléte esetén a negatív kimenetek esélye 50\%-ra nő. Ezzel együtt a védőfaktorok közül is csak az összes lehetséges tényező egy része érinti a gyermeket, ráadásul van olyan köztük, aki többet vesz igénybe, míg mások kevesebbet. Annyi elmondható, hogy minél több lehetőség áll a gyermekek rendelkezésére (tehát minél gazdagabb a repertoár ebben a három kategóriában), annál inkább képesek lesznek az adott helyzetnek leginkább megfelelő megoldást kiválasztani. A védőfaktorok, illetve a rendelkezésre álló erőforrások nagyobb száma inkább biztosít lehetőséget arra, hogy az egyén sikeresen küzdjön meg a rá háruló nehézségekkel.

Amennyiben a személyt, így a fejlődő gyermeket nagymértékủ rizikó érte, és a fejlődésmenet az optimális pályáról kisiklott, még mindig komoly szerepe lehet a protektív faktoroknak a felépülésben, a megfelelő működés és fejlődés helyreállításában. Deegan (2003) kiemeli, hogy noha minden egyén felépülési útja egyedi és komplex, számos visszatérő séma megfigyelhető, így a remény visszanyerése, a pozitív identitásérzés kialakítása, a pszichiátriai címkéktől való eltávolodás, a szimptómák kezelése, az erőteljes támogatórendszer 
kiépítése, a cél és értelem érzésének megtalálása olyan tényezők, amelyek szinte minden esetben pozitív hatással bírnak, és hozzájárulnak az egészséges működés helyreállításához.

A rizikótényezők megjelenésénél az idő rendkívül fontos. Adott hatás időtartama, illetve előfordulási gyakorisága egyaránt hatással van a fejlődés folyamatára. Ahogy arra már korábban utaltam, a fejlődést veszélyeztető és támogató faktorok kutatásának eredményei alapján különösen az elhúzódó és folyamatosan visszatérő rizikók jelentenek kockázatot (Engle, Castle és Menon, 1996).

Henley (2010) szerint különbséget kell tenni a protektív faktorok és a reziliencia között, noha más kutatók éppen egyenlőségjelet tettek a két koncepció közé. Henley úgy látja, hogy a védőfaktorok a személyen kívüli pozitív hatások, amelyek támogatják az egészséges kognitív-érzelmi fejlődést, míg a reziliencia ezeknek a faktoroknak az internalizálását, belsővé tételét jelenti, amely attitűdök és értékek fejlődésében nyilvánul meg. Ezzel egyidejüleg a személyiségen belüli védőfaktorok szerepe sem vitatható. Cohn és munkatársai (2009) vizsgálatának legfontosabb eredménye, hogy a napi szinten átélt pozitív érzelmek (tehát egy teljes mértékben személyen belüli esemény) sokkal erőteljesebben jelzik előre a növekedést, fejlődést és a rezilienciát nehézségek esetén, mint az élettel való általános elégedettség. A pozitív érzelmek, állapotok és a helyzetek pozitív tartalmú értékelése jó kimeneteket jeleznek előre az életút során. A rövid távú kognitív és érzelmi tényezők, amelyek összefüggenek a pozitív érzelmekkel, vezetnek el végül a hosszú távú fejlődéshez és növekedéshez.

Smart, Sanson, Baxter, Edwards és Hayes (2008) kiemeli, hogy a rizikó- és védőfaktorok hatása értelmezhető a gyermekek iskolára való felkészültségének és iskolai beválásának folyamatára vonatkoztatva is. Bizonyos vonatkozásokkal tehát egyértelműen kalkulálhatunk a reziliencia jellemzőin túlmutatóan az iskolával és az iskolai beválással kapcsolatosan is. Az iskolaérettséggel kapcsolatos vonatkozások bemutatása jelen tanulmánynak szintén nem képezi részét, de kapcsolódási pontként szükséges demonstrálni, hogy az egyén, a szülők-családok, illetve a közösségek szintjén értelmezett faktorok az iskolaérettség, illetve -éretlenség vonatkozásában (Smart és mtsai., 2008) egyértelmű analógiát mutatnak a rezilienciához kötődő védőfaktorokkal és kockázati tényezőkkel.

\section{Konklúzió}

Ahogy az optimális fejlődést segítő védőfaktorok, illetve erősségek-erőforrások, továbbá hozzájuk kapcsolódóan érintőlegesen a rizikótényezők áttekintése mutatja, a nehézségek és a fejlődésre ártalmas hatások széles köre érheti a gyermekeket, gyakorlatilag bármilyen kombinációban. Ezzel együtt a védőfaktorok és a rendelkezésre álló erőforrások köre is igen 
széles spektrumú. Ennek következtében a kockázatok, ártalmak, a tőlük megóvó hatások, és végső soron az egyéni szinten megnyilvánuló reziliencia minden körülmények között egyedi mintázatot mutat. A védőfaktorok, illetve a külső erőforrások biztosítása természetesen nem korlátozódhat a rizikónak kitett gyermekekre. A legtöbb esetben ezek a tényezők olyan alapvető jogokat érintenek, amelyeket minden gyermek számára biztosítani kell. A minél nagyobb számban elérhető protektív tényezők azoknak a fejlődését is képesek segíteni, akik nincsenek különösebb mértékủ rizikónak kitéve, de különös jelentőséggel bírnak a nehézségeket és hátrányokat átélö és megtapasztaló gyermekek esetében, hiszen e tényezők nélkül a fejlődésük jó eséllyel negatív irányba fordul, és nem bontakoztathatják ki a bennük rejlő potenciált. A védőfaktorok és erőforrások minél nagyobb számban történő biztosítását véleményem szerint kifejezett társadalmi érdekként szükséges szemlélni, amely a jelenleginél nagyobb mértékben teheti lehetővé sikeres, problémamentes, a társadalom szempontjából hasznos és értékes, jól funkcionáló polgárok nevelését.

\section{Irodalom}

Afifi, T. O. és MacMillan, H. L. (2011). Resilience Following Child Maltreatment: A Review of Protective Factors. La Revue canadienne de psychiatrie. 56(5), 206-272. https://doi.org/10.1177/070674371105600505

Alvord, M. K. és Johnson Grados, J. (2005). Enhancing Resilience in Children: A Proactive Approach, Professional Psychology: Research and Practice, 36(3), 238-245. https://doi.org/10.1037/0735-7028.36.3.238

Banatao, E. J. (2011). Educational Resilience: The Relationship between School Protective Factors and Student Achievement, San Diego State University, doktori disszertáció

Bass L. és Darvas Á. (2008). Gyerek jól-lét - szociálpolitika - gyerekintézmények. A tanulmány az MTA Közgazdaságtudományi Intézetének megbízásából készült (témavezető Köllő János), az Európai Unió és az Országos Foglalkoztatási Közalapítvány támogatásával

Bath, C. (2009). Learning to Belong: Exploring Young Children's Participation at the Start of School. Routledge, London. https://doi.org/10.4324/9780203879825

Benard, B. (1991). Fostering Resiliency in Kids: Protective Factors in the Family, School, and Community. Western Center for Drug-Free Schools and Communities, Portland, Oregon.

Benard, B. (1993). Fostering Resiliency in Kids. Character Education. 51(3), 44-48.

Biscoe, B. (1999). A Closer Look at Resilience: Rebounding from the Pain in the Past. University of Oklahoma, College of Continuing Education. 
Blum, R. W. (2002). Risk and Resilience: A Model for Public Health Interventions for Adolescents. University of Minnesota, Division of General Pediatrics \& Adolescent Health.

Brown, O., Howcroft, G. és Muthen, T. (2010). Resilience in Families Living with a Child Diagnosed with Hyperactivity/Attention Deficit Disorder. South African Journal of Psychology. 40 (3), 338-350. https://doi.org/10.1177/008124631004000312

Burt, M. R. (2002). Reasons to Invest in Adolescents. Journal of Adolescent Health, 31, 136-52. https://doi.org/10.1016/S1054-139X(02)00486-X

Chawla, L., Keena, K., Pevec, I. és Stanley, E. (2014). Green Schoolyards as Havens from Stress and Resources for Resilience in Childhood and Adolescence. Health \& Place, 28, 1-13. https://doi.org/10.1016/j.healthplace.2014.03.001

Christie, C. A., Harley, D. A., Nelson, C. M. és Jones, K. (2008): Promoting Resilience in Children: What Parents Can Do, Center for Effective Collaboration and Practice. American Institute of Research. cecp.air.org/familybriefs/docs/Resiliencyl.pdf

Cohn, M. A., Fredrickson, B. L., Brown, S. L., Mikels, J. A. és Conway, A. M. (2009). Happiness Unpacked: Positive Emotions Increase Life Satisfaction by Building Resilience. Emotion, 9(3), 361-368. https://doi.org/10.1037/a0015952

Cox, D. A. (2004). Leaders Fostering Resiliency in Schools. University of Pittsburgh, doktori disszertáció

Deegan, G. (2003). Discovering Recovery. Psychiatric Rehabilitation Journal, 26(4), 368-376. https://doi.org/10.2975/26.2003.368.376

Elias, M. J. és Haynes, N. M. (2008). Social Competence, Social Support, and Academic Achievement in Minority, Low-Income, Urban Elementary School Children. School Psychology Quarterly, 23(4), 474-495. https://doi.org/10.1037/1045-3830.23.4.474

Engle, P. L., Castle, S., Menon, P. (1996). Child Development: Vulnerability and Resilience. Social Science \& Medicine, 43(5), 621-635. https://doi.org/10.1016/0277-9536(96)00110-4

Erdei, Róbert (2015). Reziliencia a pedagógiában - a kockázat ellensúlyozása pedagógiai eszközökkel Pedagógusképzés: Pedagógusképzők és -továbbképzők folyóirata, 12-13, 4142, 27-43.

Erdei, Róbert (2018). A nehézségekkel való megküzdés segítése és lehetőségei. In: Toma, Kornélia; Bednarik, László; Podlovics Éva Lívia (szerk.) Iskola a határon pp. 99-114. Líceum Kiadó, Eger.

Fagan, J. és Palkovitz, R. (2007). Unmarried, Nonresident Fathers' Involvement with Their Infants: A Risk and Resilience Perspective. Journal of Family Psychology, 21(3), 479-489. https://doi.org/10.1037/0893-3200.21.3.479 
Greeff, A. P., Vansteenwegen, A. és Herbiest, T. (2011). Indicators of Family Resilience after the Death of a Child. OMEGA, 63(4), 343-358. https://doi.org/10.2190/OM.63.4.c

Grotberg, E. H. (1997a). Resilience and Culture/Ethnicity Examples from Sudan, Namibia, and Armenia. The Annual Convention of the International Council of Psychologists, Padova, Olaszország. 1997. július 21-23.

Grotberg, E. H. (1997b). The International Resilience Project. 55. Annual Convention of International Council of Psychologists 55, Graz, Ausztria. 1997. július 14-18.

Grotberg, E. H. (2003). Resilience for Today: Gaining Strength from Adversity. London, Praeger.

Guo, W-h. és Tsui, M-s. (2010). From Resilience to Resistance: A Reconstruction of the Strenghts Perspective in Social Work Practice. International Social Work. 53: 233 https://doi.org/10.1177/0020872809355391

Hart, A., Blincow, D. és Thomas, H. (2007). Resilient Therapy, Working with Children and Families. London: Routledge. https://doi.org/10.4324/9780203946893

Heller, S. S., Larrieu, J. A., D’Imperio, R. és Boris, N. W. (1999). Research on Resilience to Child Maltreatment: Empirical Considerations. Child Abuse \& Neglect. 23(4), 321-338. https://doi.org/10.1016/S0145-2134(99)00007-1

Henley, R. (2010). Resilience Enhancing Psychosocial Programmes for Youth in Different Cultural Contexts: Evaluation and Research. Progress in Development Studies, 10, 295. https://doi.org/10.1177/146499340901000403

Himelein, M. J. és McElrath, J. A. V. (1996). Resilient Child Sexual Abuse Survivors: Cognitive Coping and Illusion. Child Abuse \& Neglect. 20(8), 747-758. https://doi.org/10.1016/0145-2134(96)00062-2

Huffmann, L. C., Mehlinger, S. L. és Kerivan, A. S. (2000). Risk Factors for Academic and Behavioral Problems at the Beginning of School, Paper 1, CE-CREDIT.com, „Your Continuing Education Resource”, http://secure.ce4alliance.com/articles/9580/ riskfactorsacademic.pdf (letöltve: 2013. május 12.)

Jenkins, J. és Keating, D. (1998). Risk and Resilience in Six-and Ten-Year-Old Children. Applied Research Branch Strategic Policy, Human Resources Development Canada, Hull, Quebec, Working Paper (W-98-23E).

Jessor, R., Van Den Bos, J., Vanderryn, J., Costa, F. M. és Turbin, M. S. (1995). Protective Factors in Adolescent Problem Behavior: Moderator Effects and Developmental Change. Developmental Psychology. 31(6): 923-933 https://doi.org/10.1037/0012-1649.31.6.923 
Kim, D. H. és Yoo, I. Y. (2010). Factors Associated with Resilience of School Age Children with Cancer. Journal of Paediatrics and Child Health, 46, 431-436. https://doi.org/10.1111/j.1440-1754.2010.01749.x

Lachman, P., Poblete, X., Ebigbo, P. O., Nyandiya-Bundy, S., Bundy, R. P., Killian, B. és Doek, J. (2002). Challenges Facing Child Protection I - Lessons from the "South". Child Abuse \& Neglect, 26, 587-617. https://doi.org/10.1016/S0145-2134(02)00336-8 Laursen, E. K. és Birmingham, S. M. (2003). Caring Relationships as a Protective Factor for At-Risk Youth: An Ethnographic Study. Families in Society: The Journal of Contemporary Human Services, 84(2), 240-246.

https://doi.org/10.1606/1044-3894.101

Lösel, F. és Bender, D. (1999). Von generellen Schutzfaktoren zu differentiellen protektiven Faktoren: Ergebnisse und Probleme der Resilienzforschung. In: Opp, G., Fingerle, M. és Freytag, A. Was Kinder stärkt, Erziehung zwischen Risiko und Resilienz. München: Ernst Reinhardt.

Maier, M. (2005). Was Kinder stark macht: Resilienz - Widerstandsfähigkeit von Kindern gegenüber widrigen Lebensumständen. Akademie für Sozialarbeit, Bregenz

Malmberg, L. E. and Flouri, E. (2011). The Comparison and Interdependence of Maternal and Paternal Influences on Young Children's Behavior and Resilience. Journal of Clinical Child and Adolescent Psychology. 40(3): 434-444. https://doi.org/10.1080/15374416.2011.563469

Malvar Pargas, R. C., Brennan, P. A., Hammen, C. és Le Brocque, R. (2010). Resilience to Maternal Depression in Young Adulthood. Developmental Psychology. 46(4), 805814 https://doi.org/10.1037/a0019817

Masten, A. S. (1999). Commentary: The Promise and Perils of Resilience Research as a Guide to Preventive Interventions. In: Glantz, M. D. és Johnson, J. L. (szerk). Resilience and Development: Positive Life Adaptations. Kluwer Academic/Plenum Publishers, New York.

Masten, A. S. (2001). Ordinary Magic: Resilience Processes in Development, American Psychologist, 56(3), 227-238. https://doi.org/10.1037/0003-066X.56.3.227

Masten, A. S. és Garmezy, N. (1985). Risk, Vulnerability, and Protective Factors in Developmental Psychopathology. In: Lahey, B. és Kazdin, A. (szerk.). Advances in Clinical Child Psychology, 8, Plenum Press, New York. https://doi.org/10.1007/978-1-4613-9820-2_1

Masten, A. S. és Powell, J. L. (2003). A Resilience Framework for Research, Policy, and Practice, In: Luthar, S. S. (szerk.): Resilience and Vulnerability: Adaptation in the Context of Childhood Adversities. Cambridge University Press, New York, 1-25. https://doi.org/10.1017/CBO9780511615788.003 
Masten, A. S., Best, K. és Garmezy, N. (1990). Resilience and Development: Contributions from the Study of Children Who Overcome Adversity. Development and Psychopathology, 2, 425-444. https://doi.org/10.1017/S0954579400005812

McMillan, J. H. és Reed, D. F. (1994). At-Risk Students and Resiliency: Factors Contributing to Academic Success. The Clearing House, 67, 137-140.

https://doi.org/10.1080/00098655.1994.9956043

Mykota, D. B. és Muhajarine, N. (2005). Community Resilience Impact on Child and Youth Outcomes: A Neighborhood Case Study. Canadian Journal of School Psychology, 20(1-2), 5-20. https://doi.org/10.1177/0829573506295464

Niebank, K. és Petermann, F. (2002). Grundlagen und Ergebnisse der Entwicklungspsychopathologie. In: Petermann, F. Lehrbuch der klinischen Kinderpsychologie und-psychotherapie. 5. kiadás. Hogrefe Verlag, Göttingen.

Noltemeyer, A. L. és Bush, K. R. (2013). Adversity and Resilience: A Synthesis of International Research, School Psychology International, 34, 474-487. https://doi.org/10.1177/0143034312472758

Pajares, F. és Valiante, G. (1997). Influence of Writing Self-Efficacy Beliefs on the Writing Performance of Upper Elementary Students. Journal of Educational Research. 90, 353-360. https://doi.org/10.1080/00220671.1997.10544593

Pierce, C. (1994). Importance of Classroom Climate for At-Risk Learners. Journal of Educational Research, 88, 37-42.

Punamäki, R-L., Quota, S., Miller, T. és El-Sarraj, E. (2011). Who Are the Resilient Children in Conditions of Military Violence? Family- and Child-Related Factors in a Palestinian Community Sample. Peace and Conflict. 17, 389-416

https://doi.org/10.1080/10781919.2011.610722

Rahman, A. Y. (1999). Early Intervention or Resilience, A Case Study. AUSEINET Nemzetközi konferencia. Adelaide, Ausztrália, 1999. június 6-8.

Reed-Victor, E. (2003). Supporting Resilience of Children and Youth, Project HOPE Information Brief No. 1. Williamsburg: Virginia Department of Education.

Retzlaff, R. (2007). Families of Children with Rett Syndrome: Stories of Coherence and Resilience. Families, Systems, \& Health, 25 (3), 246-262.

https://doi.org/10.1037/1091-7527.25.3.246

Roberts, M. C. és Steele, R. C. (szerk., 2009). Handbook of Pediatric Psychology. 4. kiadás, The Guilford Press, New York

Rolf, J. E. (1999). An Interview with Norman Garmezy. In: Glantz, M. D. és Johnson, J. L. (szerk.). Resilience and Development: Positive Life Adaptations. Kluwer Academic/ Plenum Publishers, New York. 
Smart, D., Sanson, A., Baxter, J., Edwards, B. és Hayes, A. (2008). Home-to-School Transitions for Financially Disadvantaged Children, Final Report. The Smith Family, Australian Government, Australian Institute of Family Studies

Smith, L. Webber, R. és DeFrain, J. (2013). Spiritual Well-Being and Its Relationship to Resilience in Young People: A Mixed Method Case Study, SAGE Open, 3 (2), 1-16. https://doi.org/10.1177/2158244013485582

Smokowski, P. R., Reynolds, A. J. és Bezrucko, N. (1999). Resilience and Protective Factors in Adolescence: An Autobiographical Perspective from Disadvantaged Youth, Journal of School Psychology, 37 (4), 425-448.

https://doi.org/10.1016/S0022-4405(99)00028-X

Solt Á. (2012). Peremen billegö fiatalok. Veszélyeztetö és kriminalizáló tényezök gyermek-és iffúkorban, Doktori (PhD) disszertáció, kézirat, Budapest: Eötvös Loránd Tudományegyetem Társadalomtudományi Kar.

Torsheim, T., Aaroe, L. E. és Wold, B. (2001). Sense of Coherence and SchoolRelated Stress as Predictors of Subjective Health Complaints in Early Adolescence: Interactive, Indirect or Direct Relationships? Social Science \& Medicine. 53, 603614. https://doi.org/10.1016/S0277-9536(00)00370-1

Ungar, M. (2004). The Importance of Parents and Other Caregivers to the Resilience of High-Risk Adolescents. Family Process. 43 (1), 23-41.

Venters Horton, T. és Wallander, J. L. (2001). Hope and Social Support as Resilience Factors Against Psychological Distress of Mothers Who Care for Children With Chronic Physical Conditions. Rehabilitation Psychology. 46(4), 382-399.

https://doi.org/10.1037/0090-5550.46.4.382

Verlinden, S., Hersen, M. és Thomas, J. (2000). Risk Factors in School Shootings, Clinical Psychology Review, 20 (1), 3-56. https://doi.org/10.1016/S0272-7358(99)00055-0

Werner, E. E. (2000). Protective Factors and Individual Resilience. In: Skonkoff, J. P. és Meisels, S. J. (Szerk.). Handbook of Early Childhood Intervention 2. kiadás. Cambridge University Press, Cambridge. https://doi.org/10.1017/CBO9780511529320.008

Werner, E. E. és Smith, R. S. (1992). Overcoming the Odds: High Risk Children from Birth to Adulthood. Cornell University Press, New York.

https://doi.org/10.7591/9781501711992

Wills, T. A. és O’Carroll Bantum, E. (2012). Social Support, Self-Regulation and Resilience in Two Populations: General-Population Adolescents and Adult Cancer Survivors. Journal of Social and Clinical Psychology, 31 (6), 568-592.

https://doi.org/10.1521/jscp.2012.31.6.568

Wolin, S. J. és Wolin, S. (1993). The Resilient Self. New York: Villard Books. 
Wustmann, C. (2004). Resilienz. Widerstandsfähigkeit von Kindern in Tageseinrichtungen fördern. Beltz Verlag, Weinheim.

Yoo, J., Slack, K. S. és Holl, J. L. (2010). The Impact of Health-Promoting Behaviors on Low-Income Children's Health: A Risk and Resilience Perspective. Health \& Social Work, 35 (2), 133-143. https://doi.org/10.1093/hsw/35.2.133

Név: Erdei Róbert

Munkahely: B-A-Z Megyei Pedagógiai Szakszolgálat Encsi Tagintézménye; továbbá Eszterházy Károly Egyetem Sárospataki Comenius Campus

Beosztás/foglalkozás: pszichológus, tagintézmény-igazgató, adjunktus

e-mail: erdeirobert@gmail.com

Szakmai bemutatkozás: Pszichológusként dolgozom a B-A-Z Megyei Pedagógiai Szakszolgálat Encsi Tagintézményében már 10. éve. 2015 óta a Sárospataki Comenius Campuson is oktatok pedagógiai, pszichológiai és gyógypedagógiai tárgyakat. Korábban szakértői bizottságban is dolgoztam közel 10 évet, amire most újra van lehetőségem. Szakmai érdeklődésem leginkább a kognitív képességekre kiterjedő pszichológiai diagnosztika, a reziliencia jelenségköre és az óvoda-iskola átmenet kérdéseire fókuszál. 